\title{
An intracellular pH gradient in the anammox bacterium Kuenenia stuttgartiensis as evaluated by ${ }^{31} \mathrm{P}$ NMR
}

\author{
Wouter R. L. van der Star • Cor Dijkema • \\ Pieter de Waard • Cristian Picioreanu • Marc Strous • \\ Mark C. M. van Loosdrecht
}

Received: 11 August 2009 /Revised: 12 October 2009 /Accepted: 13 October 2009 /Published online: 28 October 2009

(C) The Author(s) 2009. This article is published with open access at Springerlink.com

\begin{abstract}
The cytoplasm of anaerobic ammonium oxidizing (anammox) bacteria consists of three compartments separated by membranes. It has been suggested that a proton motive force may be generated over the membrane of the innermost compartment, the "anammoxosome". ${ }^{31} \mathrm{P}$ nuclear magnetic resonance (NMR) spectroscopy was employed to investigate intracellular $\mathrm{pH}$ differences in the anammox bacterium Kuenenia stuttgartiensis. With in vivo NMR, spectra were recorded of active, highly concentrated suspensions of $K$.
\end{abstract}

W. R. L. van der Star · C. Picioreanu • M. C. M. van Loosdrecht Department of Biotechnology, Delft University of Technology, Julianalaan 67 ,

2628 BC Delft, The Netherlands

W. R. L. van der Star

Deltares,

P. O. Box 177, 2600 MH Delft, The Netherlands

C. Dijkema

Biophysics, Wageningen University and Research Centre,

Dreijenlaan 3,

6703 HA Wageningen, The Netherlands

P. de Waard

Wageningen NMR Centre,

Wageningen University and Research Centre,

Dreijenlaan 3,

6703 HA Wageningen, The Netherlands

M. Strous $(\bowtie)$

Max Planck Institute for Marine Microbiology,

Celciusstrasse 1,

28359 Bremen, Germany

e-mail: mstrous@mpi-bremen.de

\section{Strous}

Center for Biotechnology, University of Bielefeld,

Universitätsstraße 27,

33615 Bielefeld, Germany stuttgartiensis in a wide-bore NMR tube. At different external $\mathrm{pH}$ values, two stable and distinct phosphate peaks were apparent in the recorded spectra. These peaks were equivalent with $\mathrm{pH}$ values of 7.3 and 6.3 and suggested the presence of a proton motive force over an intracytoplasmic membrane in K.stuttgartiensis. This study provides for the second time-after discovery of acidocalcisome-like compartments in Agrobacterium tumefaciens-evidence for an intracytoplasmic $\mathrm{pH}$ gradient in a chemotrophic prokaryotic cell.

Keywords Anammox $\cdot$ Kuenenia stuttgartiensis . Internal $\mathrm{pH} \cdot$ In vivo NMR $\cdot$ Nuclear magnetic resonance spectroscopy $\cdot{ }^{31} \mathrm{P}$ NMR

\section{Introduction}

Anammox bacteria constitute a deeply branching monophyletic group inside the phylum Planctomycetes (Strous et al. 1999; Jetten et al. 2009). They grow by the anaerobic oxidation of ammonium with nitrite as the electron acceptor, leading to the direct production of dinitrogen gas, $\mathrm{N}_{2}$ (Van de Graaf et al. 1996). Although overlooked for almost a century of research on the nitrogen cycle, the anammox process is now known to play a major role in the production of $\mathrm{N}_{2}$ in a wide variety of (marine) ecosystems (Schmid et al. 2007) and is currently applied in wastewater treatment (Van der Star et al. 2007).

All Planctomycetes have a differentiated cytoplasm with different intracytoplasmic compartments separated by membranes (Fuerst 2005). Anammox bacteria have three compartments (Fig. 1; Strous et al. 1999; Lindsay et al. 2001; Van Niftrik et al. 2008): (1) the "riboplasm" which contains the chromosome and ribosomes, (2) the 


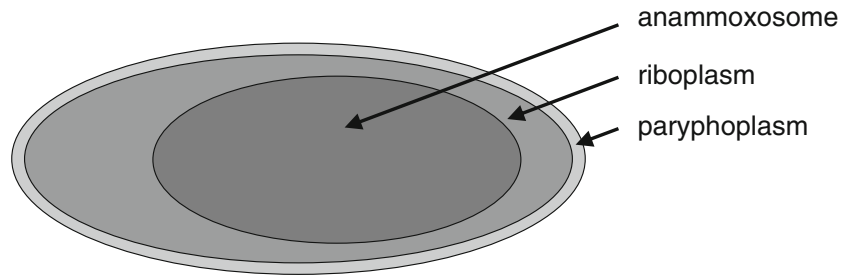

Fig. 1 Schematic representation of the different compartments in anammox bacteria (Fuerst 2005). The cytoplasm is divided into the paryphoplasm (the outer-most compartment), the riboplasm (where the ribosomes and chromosome are located), and anammoxosome (where most or all of the cytochromes $c$ are present and where the catabolism is hypothesized to take place)

"anammoxosome" located inside the riboplasm, and (3) the "paryphoplasm" that surrounds the riboplasm much like the periplasm surrounds the cytoplasm in Gramnegative bacteria. However, the Gram-negative periplasm is in open contact with the cell's surroundings via porins in the outer membrane, whereas both genomic (Strous et al. 2006) and experimental (Van Niftrik et al. 2008) evidence suggest that the paryphoplasm is not open to the environment and should be considered a cytoplasmic compartment. Whether the paryphoplasm is a true intracytoplasmic compartment as in other Planctomycetes (Lindsay et al. 2001) or whether it should be regarded a "special" periplasm - as is suggested by genome analysis (Strous et al. 2006) - is presently not clear.

For anammox bacteria, it was previously suggested that the anammoxosome contains the enzymes involved in anammox catabolism and that a proton motive force is generated over its membrane (Lindsay et al. 2001). The recent observations that all or most cytochrome $\mathrm{c}$ proteins of anammox bacteria reside inside the anammoxosome (Van Niftrik et al. 2008) and the identification of key catabolic enzymes hydrazine oxidase and hydrazine hydrolase in purified anammoxosomes (Karlsson et al. 2009) is consistent with this idea. Ladderane lipids are the most abundant membrane lipids of anammox bacteria (Rattray et al. 2008). These lipids contain concatenated cyclobutane rings and may therefore make the membranes less permeable to solutes and protons (Sinninghe Damsté et al. 2002). The slow growth rate of anammox bacteria-doubling time of several days (Strous et al. 1998; Tsushima et al. 2007; Van der Star et al. 2008) — continues to be a major challenge in anammox research. The inability to grow anammox bacteria (possibly as a result of the slow growth) in pure culture only adds to this challenge. Enrichment cultures (with typical enrichment levels of $50-90 \%$ of the population; e.g., Schmid et al. 2000; Egli et al. 2001; Strous et al. 2006; López et al. 2008) are the only source of anammox bacteria for experimental investigation. Because of the relatively large non-anammox population $(10-50 \%)$ in such cultures, additional physical purification of anammox cells (i.e., with
Percoll density gradient centrifugation; Strous et al. 1999) is necessary for unambiguous results. However, the recent enrichment of the anammox bacterium Kuenenia stuttgartiensis in a membrane bioreactor (Van der Star et al. 2008) makes it possible to obtain large amounts of suspended cells with a high degree of enrichment (up to 97.6\%), which has enabled the experiments of the present study.

In this study, the nature of the intracytoplasmic compartmentalization of cells of K.stuttgartiensis was addressed with in vivo ${ }^{31} \mathrm{P}$ NMR. In this approach, the shift of the $\mathrm{HPO}_{4}{ }^{2-} / \mathrm{H}_{2} \mathrm{PO}_{4}{ }^{-}$peak can be directly related to the $\mathrm{HPO}_{4}{ }^{2-} / \mathrm{H}_{2} \mathrm{PO}_{4}{ }^{-}$ratio and can thus be used to detect intracytoplasmic $\mathrm{pH}$ differences. The method has previously been successfully applied to estimate the (relatively acidic) vacuolar pH in several plants (Roberts et al. 1980), bacteria (Castle et al. 1986), yeasts (Nicolay et al. 1982), and fungi (Hesse et al. 2000), as well as in mitochondria (Ogawa and Lee 1984) and in thylakoid membranes in cyanobacteria (Belkin et al. 1987). In the case of thylakoids and mitochondria, the $\mathrm{pH}$ difference between the mitochondrial matrix and the cytoplasm constitutes the $\mathrm{pH}$ component of the proton motive force and has been shown to be a good indicator of cell activity. If the anammoxosome is indeed the locus of anammox catabolism, generation of a proton motive force over its membrane would be expected. The present study provides further evidence for this concept by showing that two distinct and stable $\mathrm{HPO}_{4}{ }^{2-} / \mathrm{H}_{2} \mathrm{PO}_{4}{ }^{-}$ratios are present in active cells of K.stuttgartiensis.

\section{Materials and methods}

Origin and preparation of the biomass

Biomass for all experiments was harvested from an $8 \mathrm{~L}$ anammox membrane bioreactor (MBR), fed with synthetic medium (details in Van der Star et al. 2008). The biomass retention time was 12 days, corresponding to a doubling time of 8.3 days. At the time of harvesting, the biomass concentration in the MBR was ca. 2 g-carbon/L, and the conversion was $50 \mathrm{mM} \mathrm{NH_{4 }}{ }^{+} /$day. $K$. stuttgartiensis $(100 \%$ sequence similarity of the $16 \mathrm{~S}$ rRNA with the Kuenenia from the Kölliken enrichment) was the only anammox species that could be detected (with fluorescence in situ hybridization) and constituted $97.6 \%$ of the population (Van der Star et al. 2008). Biomass collected during 3-4 days was concentrated 100 times in a single centrifugation step and used for in vivo NMR experiments within $24 \mathrm{~h}$ after concentration. The biomass produced by this procedure was dark red and highly viscous, but still liquid. Further concentration was not possible and led to 
degradation of the biomass, resulting in extensive foaming. Cells remained in suspension up to 5 days after preparation.

\section{NMR}

${ }^{31} \mathrm{P}$ NMR spectra were recorded at $121.5 \mathrm{MHz}$ on a Bruker AV-300 (Bruker Rheinstetten, DE, Germany) wide-bore spectrometer equipped with a ${ }^{31} \mathrm{P} /{ }^{13} \mathrm{C}$ probe (diameter $20 \mathrm{~mm}$ ) and collected in 60-min blocks of 6,700 scans. Temperature was controlled at $298 \mathrm{~K}$. Spectra were calibrated by the NADH/NADPH peak at $10.9 \mathrm{ppm}$. pH values were determined by comparing the $\mathrm{pH}$-sensitive shifts of inorganic phosphate in the cytoplasm with a calibration curve for inorganic phosphate (Den Hollander et al. 1981).

\section{In vivo fed-batch NMR}

For the experiment, the $20 \mathrm{~mm}$ NMR tube was employed as a miniature fed-batch reactor (Fig. 2). Ten to fifteen milliliters of concentrated biomass was added to the NMR tube. Mixing and anoxic conditions were maintained by sparging continuously with $\mathrm{N}_{2}$. Ammonium nitrite $(200 \mathrm{mM})$ was added as the substrate via a syringe pump at $1 \mathrm{~mL} / \mathrm{h}$ for 1 to $20 \mathrm{~h}$. The first spectra were recorded without substrate supply or $\mathrm{N}_{2}$ flushing. Subsequently, spectra were recorded for 1-2 $\mathrm{h}$ while the tube was flushed with $\mathrm{N}_{2}$ without substrate supply. Finally, spectra were recorded during 1-4 h with substrate supply and flushing with $\mathrm{N}_{2}$. For experiments at different external $\mathrm{pH}$ values, the concentrated cell solution was buffered with 200-400 mM HEPES (4-(2-hydroxyethyl)-1piperazineethanesulfonic acid) buffer at $\mathrm{pH} 6.5,6.9,7.4$, and 7.8. After $1 \mathrm{~h}$ of anoxic conditions without substrate supply, $200 \mathrm{mM}$ ammonium nitrite solution was added for $2 \mathrm{~h}$.

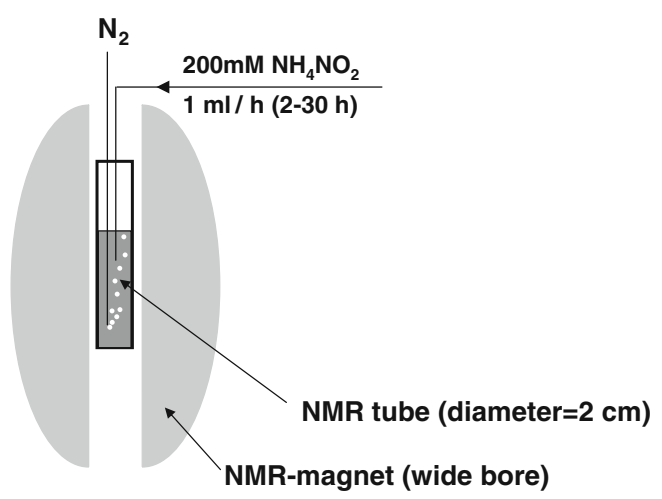

Fig. 2 The experimental setup for in vivo ${ }^{31} \mathrm{P}$ NMR employing a high purity, well-mixed anammox culture consisting of fully suspended $K$. stuttgartiensis cells

\section{Results}

Response to anoxic conditions and feed of ammonium nitrite

The cell suspension was harvested from the membrane bioreactor, concentrated to $15 \mathrm{~mL}$, transferred to a $20 \mathrm{~mm}$ (i.d.) wide-bore NMR tube, and mounted into the $300 \mathrm{MHz}$ NMR machine, which was tuned for ${ }^{31} \mathrm{P}$ at $121.5 \mathrm{MHz}$ (see "Materials and methods"). K. stuttgartiensis was shown to constitute $97.6 \%$ of the cells in the suspension. The ${ }^{31} \mathrm{P}$ NMR spectra for this experiment are shown in Fig. 3. Initially, the suspension was supposedly oxic, since no efforts were made to maintain anoxic conditions and the oxygen consumption rate of the suspension was below the detection limit (Van der Star et al. 2008). The initial spectra displayed two distinct peaks: the first at $2.52 \mathrm{ppm}$ (corresponding to $\mathrm{pH} 7.1$, which was the medium $\mathrm{pH}$ ) and a peak of lower intensity at $1.55 \mathrm{ppm}$ (corresponding to $\mathrm{pH}$ 6.4, see Fig. 3 I). After removal of any remaining oxygen by $\mathrm{N}_{2}$ sparging, the peak at $2.52 \mathrm{ppm}(\mathrm{pH} 7.1)$ shifted to $3.1 \mathrm{ppm}$ (pH7.8) but retained its shape (Fig. 3 II). Because of this peak shift, a shoulder in the recorded spectrum became apparent (2.84 ppm, pH7.4; Fig. 3 II and III). pH

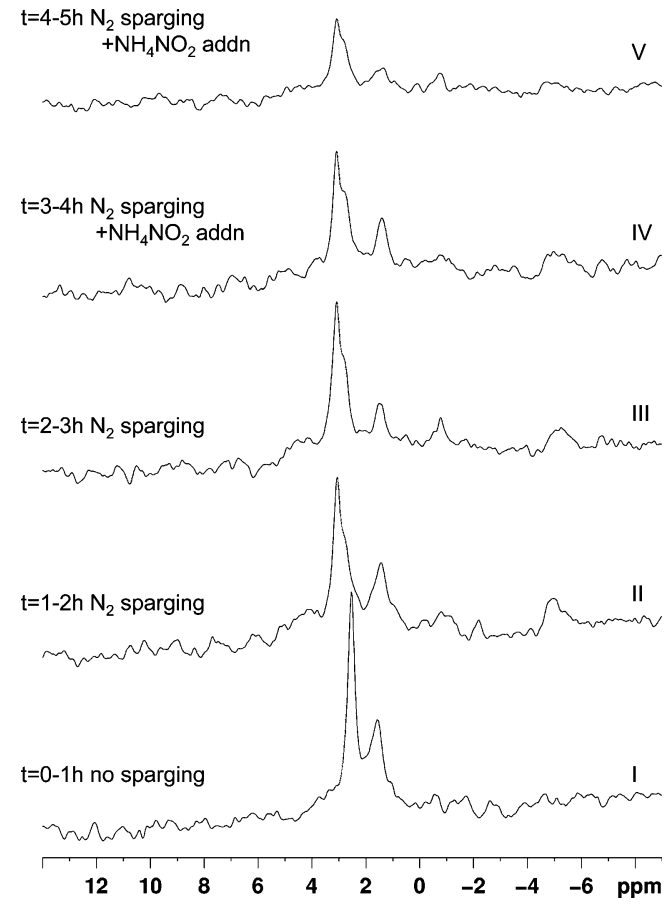

Fig. 3 In vivo ${ }^{31} \mathrm{P}$ spectra of resting $K$. stuttgartiensis cells under nongassed conditions $(I)$ and under dinitrogen gas sparging conditions (IIIII). There is a shift in the main phosphate peak from $2.52(\mathrm{pH} 7.1 \mathrm{in} I)$ to $3.1 \mathrm{ppm}(\mathrm{pH} 7.8 \mathrm{in} I I)$, while a shoulder appears at $2.84 \mathrm{ppm}(\mathrm{pH} 7.4$ in II). A peak at $1.55 \mathrm{ppm}$ (pH6.4) is present throughout the experiment. Start of the active conversion of catabolic substrates ammonium and nitrite $(I V-V)$ does not significantly change the pattern. Acquisition time $=1 \mathrm{~h}(6,700$ spectra $)$ 
measurement at the end of the experiment confirmed that the $\mathrm{pH}$ of the solution had shifted to 7.8 and that the $3.1 \mathrm{ppm}$ peak could thus be assigned to the extracellular environment. Although metabolic activity could be also of importance, this $\mathrm{pH}$ increase was probably due to the removal of $\mathrm{CO}_{2}$ from the medium which was not sufficiently buffered.

During $\mathrm{N}_{2}$ sparging, the smaller peak at $1.55 \mathrm{ppm}$ shifted to a slightly more acid value (1.43 ppm, pH6.3, Fig. 3 II and III). After the induction of anammox activity by substrate supply, the peaks remained at these values (Fig. 3 IV and V).

To investigate the stability of the observed peaks, $K$. stuttgartiensis cell suspensions were harvested, concentrated, and resuspended in HEPES buffers with different $\mathrm{pH}$ values. Figure 4 shows the intra- and extracellular $\mathrm{pH}$ values derived from the recorded spectra and confirms that the position of the main peak corresponded to the external $\mathrm{pH}$. Furthermore, the peak, which was previously present as a shoulder at $\mathrm{pH} 7.4$, as well as the smaller peak at $\mathrm{pH} 6.4$ always remained at the same positions. At medium pH6.9 and 7.4, only two peaks were present (at the medium $\mathrm{pH}$ and at $\mathrm{pH} 6.3$ ) as the compartment responsible for the peak around 7.3-7.4 ppm was too close - or equal - to the medium $\mathrm{pH}$ to a give a clearly independent peak/shoulder.

To show that the K. stuttgartiensis cells had been active in the previous incubations, spectra were also recorded during a longer time ( $4 \mathrm{~h}, 26,800$ spectra) to increase the sensitivity in order to enable the detection of phosphatecontaining organic metabolites. Besides the abovementioned peaks of the inorganic phosphate species, these spectra showed peaks at $-18.6,-10.8,-5.2,-0.8,4.1$, and $4.5 \mathrm{ppm}$ (Fig. 5). The peaks at -18.6 and -5.2 could be ascribed to $\gamma$ - and $\beta$-ATP, respectively, whereas the peak

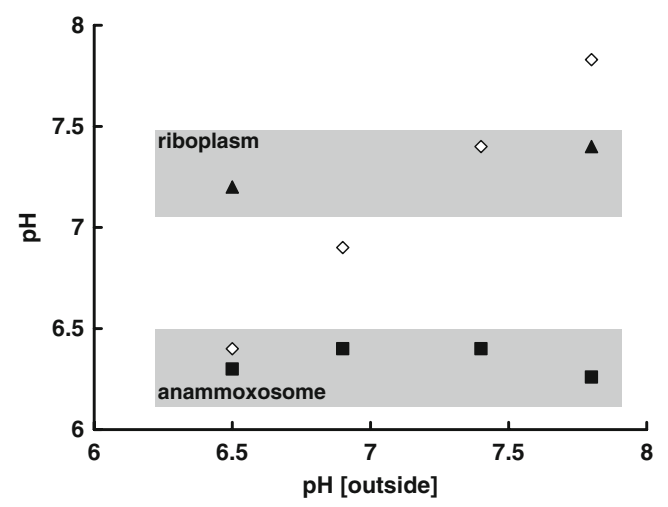

Fig. $4 \mathrm{pH}$ values in the intracytoplasmic compartments of cells of $K$. stuttgartiensis as revealed by ${ }^{31} \mathrm{P}$ NMR. Symbols represent the assigned $\mathrm{pH}$ for: diamonds extracellular medium, squares anammoxosome compartment, and triangles riboplasm compartment. At pH6.9 and 7.4, the $\mathrm{pH}$ of the riboplasmic compartment was too close to the medium $\mathrm{pH}$ to a give a clearly independent peak/shoulder at -10.8 was NADH/NADPH. The peak at -0.8 is consistent with phosphoenolpyruvate (PEP). The peaks above $4 \mathrm{ppm}$ may indicate the presence of a phosphate esthers (a monoesther at $4.5 \mathrm{ppm}$ and a diesther at 4.1). No signs of poly-phosphate were found.

\section{Discussion}

Allocation of the peaks

The experiments clearly showed that apart from the external medium, two intracytoplasmic compartments were present with $\mathrm{pH}$ values of 7.3 and 6.3. These $\mathrm{pH}$ values were maintained over an external $\mathrm{pH}$ range from 6.5 to 7.8 (Fig. 4). This observation can be explained in several ways. Firstly, it may be possible that the two $\mathrm{pH}$ values resulted from two different populations. However, since the cell suspension that was used contained only very few cells that were not K. stuttgartiensis (Van der Star et al. 2008), this is unlikely. Even if other bacteria contributed to the NMR signal, a minor contribution to the $\mathrm{pH} 7.3$ peak would be expected rather than the production of a second acidic peak at pH6.3, since the cytoplasm of these-presumably uncompartmentalized - contaminants would be expected to have neutral or slightly alkaline $\mathrm{pH}$ relative to the external medium.

Second, it may be possible that the K. stuttgartiensis population was in two different physiological states, resulting in two distinct $\mathrm{pH}$ values of the cytoplasm. This was also unlikely, because vigorous mixing of the NMR tube by sparging of $\mathrm{N}_{2}$ and addition of substrates did not cause the disappearance of either of the two peaks. Thus, the population must have been physiologically homogeneous.

Third - and most plausibly - the two peaks may have resulted from the presence of two intracytoplasmic compartments with different $\mathrm{pH}$ values. The allocation of the peaks to different compartments (anammoxosome, riboplasm, and paryphoplasm) cannot be assessed directly by ${ }^{31} \mathrm{P}$ NMR. Although the allocation of peaks to specific compartments is usually verified with $\mathrm{pH}$-sensitive fluorophores, this is impossible for $K$. stuttgartiensis, since these molecules cannot pass the ladderane membranes of living anammox bacteria (Sinninghe Damsté et al. 2002).

If the anammoxosome indeed plays a role in energy generation (see below), then a $\mathrm{pH}$ gradient would be expected over the anammoxosome membrane. All presently available experimental evidence indicates that the final metabolic step of the anammox catabolism-hydrazine oxidation to dinitrogen gas (Van de Graaf et al. 1997; Strous et al. 2006; Karlsson et al. 2009)—-takes place inside the anammoxosome. This step feeds four electrons into the 
Fig. 5 Full in vivo ${ }^{31} \mathrm{P}$ spectra of $K$. stuttgartiensis converting ammonium nitrite. Acquisition time $=4 \mathrm{~h}(26,800$ spectra $)$, line width $=25 \mathrm{~Hz}$. The three $\mathrm{pH}$ related peaks are $1.5 \mathrm{ppm}$ ( $\mathrm{pH} 6.3$, assigned to the anammoxosome), $2.9 \mathrm{ppm}$ (shoulder, $\mathrm{pH} 7.4$, assigned to the riboplasm), and $3.1 \mathrm{ppm}$ ( $\mathrm{pH} 7.8$, the extracellular $\mathrm{pH}$ ). Four non-pH peaks are visible at $-18.6,-10.8,-5.2,-0.8,4.1$, and $4.5 \mathrm{ppm}$, which can probably be assigned to $\beta$-ATP (-18.6), NAD/NADP (-10.8 ppm), $\gamma$-ATP (-5.2), phosphoenolpyruvate (PEP, $-0.8 \mathrm{ppm}$ ). The peaks at 4.1 and $4.5 \mathrm{ppm}$ are probably a phosphate diesther and a phosphate monoesther, respectively

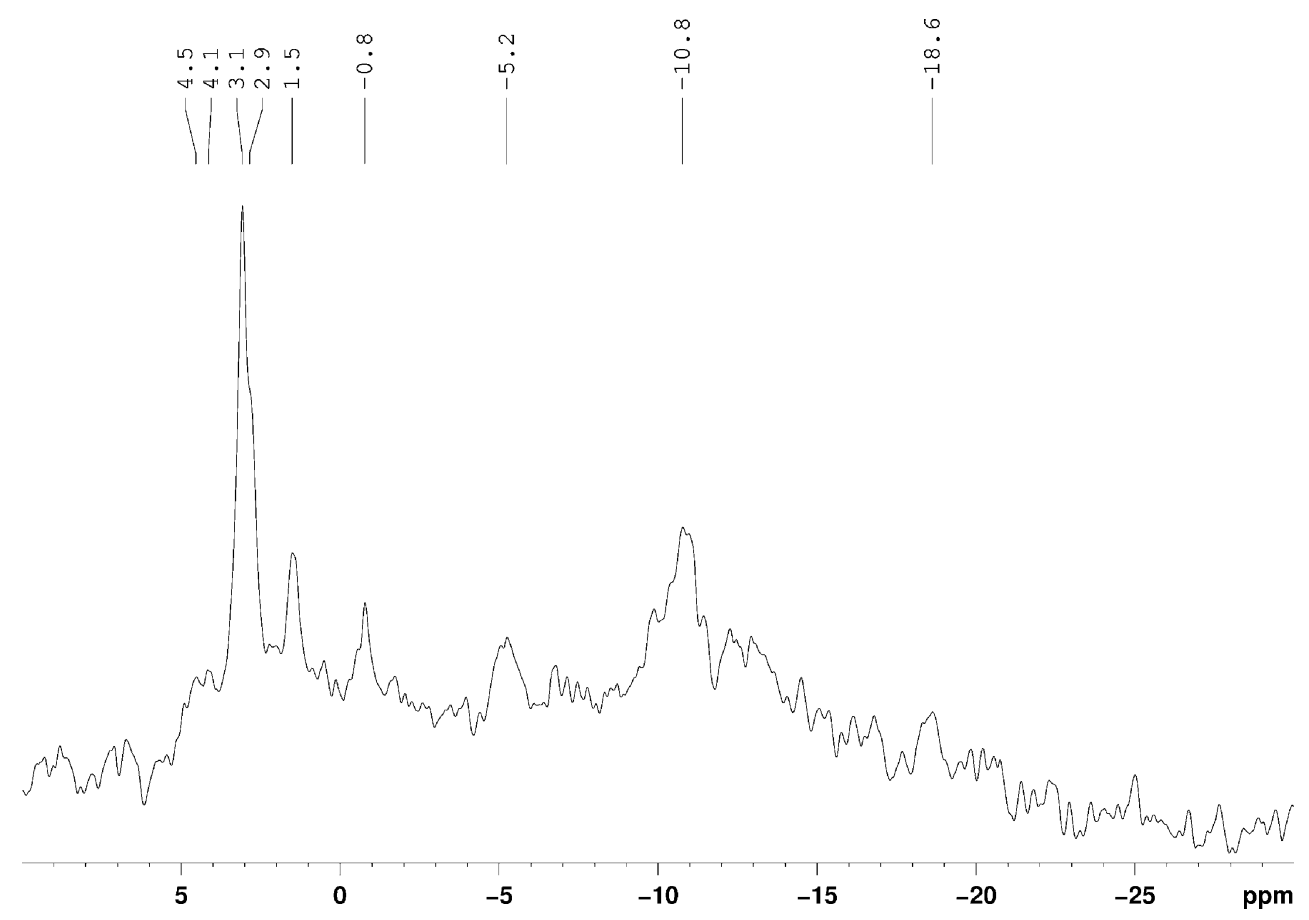

respiratory chain and simultaneously releases four protons. Thus, this step has the potential to acidify the anammoxosome and build up a proton motive force over its membrane. The attribution of the lower $\mathrm{pH}$ value of the present study to the anammoxosome is therefore the only one consistent with previous experimental evidence.

The detection of two compartments at different $\mathrm{pH}$ is not necessarily inconsistent with an anammox cell consisting of three separate compartments. In the first place, it is possible that no $\mathrm{pH}$ gradient exists between two of the three compartments (for example the riboplasm and the paryphoplasm). Second, it is possible that no $\mathrm{pH}$ gradient exists between the paryphoplasm and the external medium. That would be expected if the anammox paryphoplasm is actually more similar to the Gram-negative periplasm (Strous et al. 2006). Finally, the third compartment may have been too small (and/or may not contain enough phosphate) to be visible with ${ }^{31} \mathrm{P}$ NMR.

Follow-up studies will have to provide further evidence for these conclusions by investigation of the response of the observed differences in $\mathrm{pH}$ to different physiological conditions (e.g., de-energizing the pmf by inducing starvation or the addition of uncouplers).

The anammoxosome as the location for energy generation

Since the proton motive force in general is constant for a given organism, also a more or less constant $\mathrm{pH}$ difference is expected between the two sides of the membrane over which the proton motive force is created. In bacteria, this generally results in a constant $\mathrm{pH}$ difference between the outside $\mathrm{pH}$ and the cytoplasm. In the investigated anammox bacterium, this constant difference was not found. But since two internal compartments exerted a $\mathrm{pH}$ which was independent of the outside $\mathrm{pH}$, it seems logical that the proton motive force was generated over this membrane. To our knowledge, cyanobacterial thylakoids (Belkin et al. 1987 ) and the acidic acidocalcisome-like compartment in Agrobacterium tumefaciens (Seufferheld et al. 2003) are the only other reported compartment in a prokaryote, in which the proton motive force was shown to take place.

The proton motive force in bacteria generally constitutes a more or less constant potential of circa $150-200 \mathrm{mV}$. If the proton motive force is generated over the anammoxosome membrane, with a $\mathrm{pH}$ difference of 1.0 , then the $\mathrm{pH}$ component of the proton motive force is circa $60 \mathrm{mV}$ for $K$. stuttgartiensis. If our interpretation is correct, the anammoxosome is functionally similar to mitochondria in eukaryotic cells as both these compartments (organelles) would provide the cell with energy in the form of ATP. Also the $\mathrm{pH}$ difference between mitochondria and the cytosol in eukaryote - e.g., 35-53 mV for rat liver (Ogawa and Lee 1984) and $60 \mathrm{mV}$ in human hepatocytes (liver cells, Hoek et al. 1980; Strzelecki et al. 1984) —is similar to the estimated $\mathrm{pH}$ difference found between the anammoxosome and the cytoplasm. In contrast to the anammoxosome, the $\mathrm{pH}$ in mitochondria is - instead of being more acidicabout one unit more alkaline. Therefore, the orientation of the membrane-bound ATP synthases must be reversed compared to mitochondria (and thus similar to the cyanobacterial intrathylakoid space): Whereas in mitochondria the ATP synthesizing domain of the ATP synthase is 
directed toward the mitochondrial matrix, it can be expected to be directed toward riboplasm in anammox bacteria (Van Niftrik et al. 2004). A similar orientation was shown for ATP synthases in the intrathylakoid space, in which the compartment is also the more acidic then the cytoplasm. In the latter case however, much larger $\mathrm{pH}$ differences are found (Belkin et al. 1987).

\section{Function of PEP}

The production of PEP immediately upon energizing the system is consistent with the acetyl CoA route, which is the most probable $\mathrm{CO}_{2}$ fixation pathway of anammox bacteria (Schouten et al. 2004; Strous et al. 2006). The production of this metabolite upon addition of the substrates ammonium and nitrite is another indicator that the cells were actively metabolizing during the experiment. The same can probably be concluded from production of the (unidentified) phosphate mono ester.

Acknowledgments We thank Mike Jetten, Laura van Niftrik, and Boran Kartal for helpful discussions. This research was supported by the Technology Foundation STW (grant NPC.5987).

Open Access This article is distributed under the terms of the Creative Commons Attribution Noncommercial License which permits any noncommercial use, distribution, and reproduction in any medium, provided the original author(s) and source are credited.

\section{References}

Belkin S, Mehlhorn RJ, Packer L (1987) Proton gradients in intact cyanobacteria. Plant Physiol 84(1):25-30

Castle AM, Macnab RM, Shulman RG (1986) Coupling between the sodium and proton gradients in respiring Escherichia coli cells measured by ${ }^{23} \mathrm{Na}$ and ${ }^{31} \mathrm{P}$ nuclear magnetic resonance. J Biol Chem 261(17):7797-7806

Den Hollander JA, Ugurbil K, Brown TR, Shulman RG (1981) Phosphorus-31 nuclear magnetic resonance studies of the effect of oxygen upon glycolysis in yeast. Biochemistry 20(20):5871-5880

Egli K, Fanger U, Alvarez PJJ, Siegrist H, Van der Meer JR, Zehnder AJB (2001) Enrichment and characterization of an anammox bacterium from a rotating biological contactor treating ammonium-rich leachate. Arch Microbiol 175(3):198-207

Fuerst JA (2005) Intracellular compartmentation in Planctomycetes. Annu Rev Microbiol 59:299-328

Hesse SJA, Ruijter GJG, Dijkema C, Visser J (2000) Measurement of intracellular (compartmental) $\mathrm{pH}$ by ${ }^{31} \mathrm{P}$ NMR in Aspergillus niger. J Biotechnol 77(1):5-15

Hoek JB, Nicholls DG, Williamson JR (1980) Determination of the mitochondrial protonmotive force in isolated hepatocytes. J Biol Chem 255(4):1458-1464

Jetten MSM, van Niftrik L, Strous M, Kartal B, Keltjens JT, Op den Camp HJM (2009) Biochemistry and molecular biology of anammox bacteria. Crit Rev Biochem Mol Biol 44(2-3):65-84

Karlsson R, Karlsson A, Baeckman O, Johansson BR, Hulth S (2009) Identification of key proteins involved in the anammox reaction. FEMS Microbiol Lett 297(1):87-94
Lindsay MR, Webb RI, Strous M, Jetten MSM, Butler MK, Forde RJ, Fuerst JA (2001) Cell compartmentalization in Planctomycetes: novel types of structural organisation for the bacterial cell. Arch Microbiol 175(6):413-429

López H, Puig S, Ganigué R, Ruscalleda M, Balaguer MD, Colprim J (2008) Start-up and enrichment of a granular anammox SBR to treat high nitrogen load wastewaters. J Chem Technol Biotechnol $83: 233-241$

Nicolay K, Scheffers WA, Bruinenberg PM, Kaptein R (1982) Phosphorus-31 nuclear magnetic resonance studies of intracellular $\mathrm{pH}$, phosphate compartmentation and phosphate transport in yeasts. Arch Microbiol 133(2):83-89

Ogawa S, Lee TM (1984) The relation between the internal phosphorylation potential and the proton motive force in mitochondria during ATP synthesis and hydrolysis. J Biol Chem 259(16):10004-10011

Rattray JE, van de Vossenberg J, Hopmans EC, Kartal B, van Niftrik L, Rijpstra WIC, Strous M, Jetten MSM, Schouten S, Damste JSS (2008) Ladderane lipid distribution in four genera of anammox bacteria. Arch Microbiol 190(1):51-66

Roberts JKM, Ray PM, Wade-Jardetzky N, Jardetzky O (1980) Estimation of cytoplasmic and vacuolar $\mathrm{pH}$ in higher plant cells by phosphorus-31 NMR. Nature (London, United Kingdom) 283 (5750):870-872

Schmid M, Twachtmann U, Klein M, Strous M, Juretschko S, Jetten M, Metzger JW, Schleifer K-H, Wagner M (2000) Molecular evidence for genus level diversity of bacteria capable of catalyzing anaerobic ammonium oxidation. Syst Appl Microbiol 23(1):93-106

Schmid MC, Risgaard-Petersen N, Van de Vossenberg J, Kuypers MMM, Lavik G, Petersen J, Hulth S, Thamdrup B, Canfield D, Dalsgaard T, Rysgaard S, Sejr MK, Strous M, Op den Camp HJM, Jetten MSM (2007) Anaerobic ammonium-oxidizing bacteria in marine environments: widespread occurrence but low diversity. Environ Microbiol 9(6):1476-1484

Schouten S, Strous M, Kuypers MMM, Rijpstra WIC, Baas M, Schubert CJ, Jetten MSM, Sinninghe Damsté JS (2004) Stable carbon isotopic fractionations associated with inorganic carbon fixation by anaerobic ammonium-oxidizing bacteria. Appl Environ Microbiol 70(6):3785-3788

Seufferheld M, Vieira MCF, Ruiz FA, Rodrigues CO, Moreno SNJ, Docampo R (2003) Identification of organelles in bacteria similar to acidocalcisomes of unicellular eukaryotes. J Biol Chem 278 (32):29971-29978

Sinninghe Damsté JS, Strous M, Rijpstra WIC, Hopmans EC, Geenevasen JAJ, Van Duin ACT, Van Niftrik LA, Jetten MSM (2002) Linearly concatenated cyclobutane lipids form a dense bacterial membrane. Nature (London) 419(6908):708-712

Strous M, Heijnen JJ, Kuenen JG, Jetten MSM (1998) The sequencing batch reactor as a powerful tool for the study of slowly growing anaerobic ammonium-oxidizing microorganisms. Appl Microbiol Biotechnol 50(5):589-596

Strous M, Fuerst JA, Kramer EHM, Logemann S, Muyzer G, Van de Pas-Schoonen KT, Webb R, Kuenen JG, Jetten MSM (1999) Missing lithotroph identified as new Planctomycete. Nature (London) 400(6743):446-449

Strous M, Pelletier E, Mangenot S, Rattei T, Lehner A, Taylor MW, Horn M, Daims H, Bartol-Mavel D, Wincker P, Barbe V, Fonknechten N, Vallenet D, Segurens B, Schenowitz-Truong C, Medigue C, Collingro A, Snel B, Dutilh BE, Op den Camp HJM, Van der Drift C, Cirpus I, Van de Pas-Schoonen KT, Harhangi HR, Van Niftrik L, Schmid M, Keltjens J, Van de Vossenberg J, Kartal B, Meier H, Frishman D, Huynen MA, Mewes H-W, Weissenbach J, Jetten MSM, Wagner M, Le Paslier D (2006) Deciphering the evolution and metabolism of an anammox bacterium from a community genome. Nature (London) 440(7085):790-794 
Strzelecki T, Thomas JA, Koch CD, LaNoue KF (1984) The effect of hormones on proton compartmentation in hepatocytes. J Biol Chem 259(7):4122-41229

Tsushima I, Kindaichi T, Okabe S (2007) Quantification of anaerobic ammonium-oxidizing bacteria in enrichment cultures by real-time PCR. Water Res 41(4):785-794

Van de Graaf AA, De Bruijn P, Robertson LA, Jetten MSM, Kuenen JG (1996) Autotrophic growth of anaerobic ammonium-oxidizing microorganisms in a fluidized bed reactor. Microbiology (Reading, United Kingdom) 142(8):2187-2196

Van de Graaf AA, De Bruijn P, Robertson LA, Jetten MSM, Kuenen JG (1997) Metabolic pathway of anaerobic ammonium oxidation on the basis of ${ }^{15} \mathrm{~N}$ studies in a fluidized bed reactor. Microbiology (Reading, United Kingdom) 143(7):2415-2421

Van der Star WRL, Abma WR, Blommers D, Mulder JW, Tokutomi T, Strous M, Picioreanu C, Van Loosdrecht MCM (2007) Startup of reactors for anoxic ammonium oxidation: experiences from the first full-scale anammox reactor in Rotterdam. Water Res 41 (18):4149-4163

Van der Star WRL, Miclea AI, Van Dongen LGJM, Muyzer G, Picioreanu C, Van Loosdrecht MCM (2008) The membrane bioreactor: a novel tool to grow anammox bacteria as free cells. Biotechnol Bioeng 101(2):286-294

Van Niftrik LA, Fuerst JA, Sinninghe Damsté JS, Kuenen JG, Jetten MSM, Strous M (2004) The anammoxosome: an intracytoplasmic compartment in anammox bacteria. FEMS Microbiol Lett 233 (1):7-13

Van Niftrik L, Geerts WJC, Van Donselaar EG, Humbel BM, Webb RI, Fuerst JA, Verkleij AJ, Jetten MSM, Strous M (2008) Linking ultrastructure and function in four genera of anaerobic ammoniumoxidizing bacteria: cell plan, glycogen storage and localization of cytochrome c proteins. J Bacteriol 190(2):708-717 